\title{
STAVEBNÍ MATERIÁL HRADU ŠPILBERK A JEHO VÝVOJ
}

\section{ALEŠ NAVRÁTIL - MONIKA MARTINISKOVÁ - JAN PETŘÍK - DALIBOR VŠIANSKÝ}

\begin{abstract}
Abstrakt: Archeologický a stavebně historický výzkum v rámci rekonstrukce jižního křidla Špilberku v letech 2011-2012 přinesl celou řadu nových poznatkủ o minulosti hradu. V předkládaném př́spěvku využiváme ziskaná data týkající se zejména stavebně technické keramiky v kombinaci s makroskopickým a mikroskopickým vzorkováním prírodního stavebního materiálu. Po konfrontaci se staršimi poznatky nám výsledky umožni sestavit hypotetickou posloupnost vývoje hradu od rané gotiky do barokni prestavby. Klíčová slova: Špilberk - hrad-stavební materiál-raná gotika.
\end{abstract}

\section{The Building Material of Špilberk Castle and its Development}

Abstract: Archaeological and building-historical research carried out during the reconstruction of the south wing of Špilberk Castle in 2011-2012 brought a great deal of new information about the castle's past. This contribution presents the newly acquired data regarding, in particular, the building and technical ceramics in combination with macroscopic and microscopic samples of the natural building material. Comparison with earlier data will enable the drafting of a hypothetical sequence of the castle's development from the early Gothic until its baroque reconstruction.

Key words: Špilberk - castle - building material - early Gothic.

\section{Úvod}

V roce 1984 byla zahájena stavební rehabilitace areálu hradu a pevnosti Špilberk. Rekonstrukční práce s kratšími či delšími přestávkami pokračují až do současnosti. Nejrozsáhlejší stavební akci posledních let představovala obnova jižního křídla hradu. Záchranný archeologický výzkum prováděný $\mathrm{v}$ letech 2011-2012 v rámci stavby přinesl důležité poznatky o vývoji Špilberku. Mimo jiné vydal také bohatou kolekci stavební keramiky a umožnil četná stavebně historická pozorování. Získaný archeologický materiál a stavebně historická data poskytly ideální př́ležitost pro nové vyhodnocení stavebního vývoje hradu a revizi dosavadních poznatků. $\mathrm{Na}$ následujících řádcích je provedeno zhodnocení stavebně technické keramiky z výzkumu v jižním kř́́dle a vzorkové vyhodnocení kvantitativního zastoupení geologického stavebního materiálu v různých částech hradu včetně analýzy užitých malt. Výsledky jsou spojeny do interpretačního rámce.

\section{Stručná historie hradu Špilberku}

Národní kulturní památka Hrad a pevnost Špilberk se nachází na výrazném kopci v bezprostřední blízkosti historického jádra města Brna, se kterým v minulosti tvořil nedílnou strategickou jednotku. Nejstarší historická zmínka vztahující se k hradu pochází z roku 1277 (Flodrová 1988; Plaček 2013, 615). Tradičně se tak jako zakladatel Špilberku uvádí Přemysl Otakar II., někteří badatelé se však domnívají, že hrad mohl být založen již Václavem I. (srov. CejnkováLoskotová-Plaček 1995, 156; Kuča 2000, 548). Současný stav bádání nám zatím bohužel nedovoluje na tuto otázku jednoznačně odpovědět. Významné období v dějinách hradu představuje druhá polovina 14. století a počátek století patnáctého, kdy byl Špilberk rezidenčním sídlem moravských markrabat rodu Lucemburků. Od 20. let 15. století se hrad dostával střídavě do správy a zástavy. Tato situace trvala až do roku 1560, kdy Špilberk koupilo město. Nejpravděpodobněji v roce 1593 došlo k vybudování renesančního opevnění, které obklopilo gotický hrad ze všech stran (Navrátil 2013). Po úspěšném odolání švédskému obležení v roce 1645 se stalo Brno zemskou pevností a Špilberk byl proměněn na barokní citadelu tvořící součást brněnské bastionové pevnosti. Následné přestavby, které byly v různých intervalech realizovány prakticky až do 20. století, zničily valnou většinu toho, co z gotického hradu zbylo. Díky archeologickým a sta- 


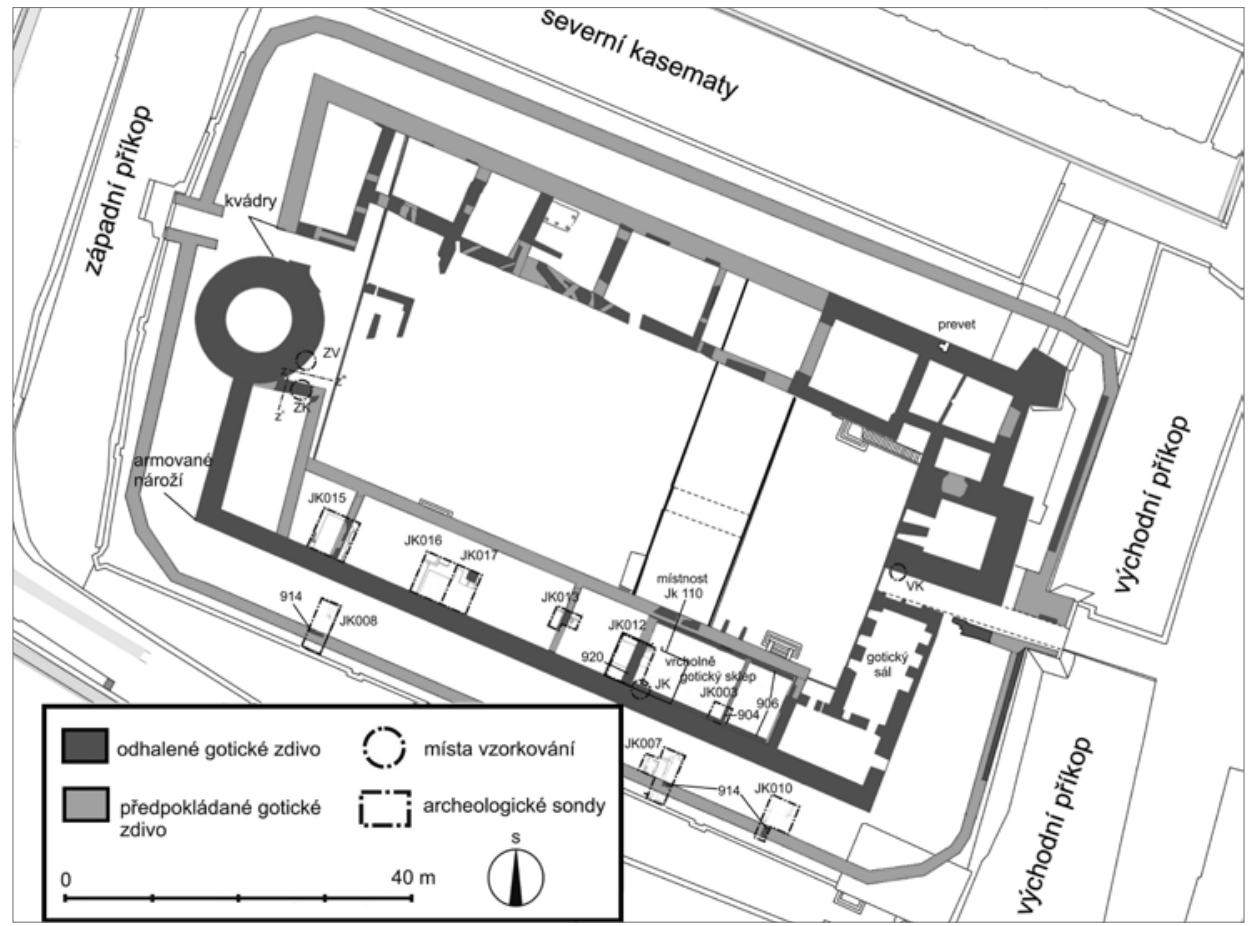

Obr. 1. Plán gotického zdiva Špilberku s vyznačenými sondami v jižním kř́́dle a vzorkovaných míst.

Abb. 1. Planskizze des gotischen Mauerwerks der Burg Spielberg mit eingezeichneten Sondiergrabungen im Südflügel und den Probeentnahmestellen.

vebně historickým výzkumům probíhajícím od roku 1984 se podařilo zrekonstruovat jeho hlavní půdorysnou dispozici. Mnohé otázky ohledně jeho stavebního vývoje však zůstávají stále otevřené.

\section{Stavební keramika $\mathrm{z}$ archeologických sond $\mathrm{v}$ jižním křídle}

V roce 2011 byly zahájeny stavební práce na rekonstrukci jižního křídla - poslední části hradu, která nebyla dotčena rekonstrukcemi z předchozích let. Jelikož se zasahovalo do zásypů podlah jen výjimečně - na rozdíl od starších stavebních akcí -, byl archeologický výzkum proveden formou devíti archeologických sond, jejichž cílem bylo získat co největší množství stratigrafických informací, které by umožnily rozšiřit a zpřesnit dosavadní poznatky o vývoji hradu (obr. 1). Šest sond bylo položeno v prostoru vnitřního hradu (JK003, JK012, JK013, JK015, JK016, JK017), tři sondy pak v prostoru gotického parkánu (JK007, JK008, JK010). Mimo zděné konstrukce byla výplň sond tvořena $z$ valné většiny sut’ovými vyrovnávacími zásypy, jejichž součástí byl soubor cihel, dlaždic a střešní krytiny.

Z archeologických situací bylo vyzvednuto 101 kusů cihel, které se zachovaly alespoň z poloviny své původní velikosti. $Z$ tohoto počtu bylo 52 kusů celých. Soubor obsahoval gotické cihly malého a vysokého formátu, jednu klenačku a jednu cihlu zvláštního rozměru. Cihly malého formátu měly rozměry $19,5-20,8 \times 9,3-10 \times 4,3-5 \mathrm{~cm}$. Tyto cihly byly dokumentovány i ve stojících konstrukcích, kde byly využity jako doplňkový stavební materiál k lomovému kameni a tesaným kamenickým článkům, a to nejčastěji jako výplně kleneb a zaklenutí výklenků. Objevují se také jako druhotně použité v mladších konstrukcích. Cihly malého formátu se vyskytovaly na území Brna ve 13. století, jejich používání končí na přelomu století třináctého a čtrnáctého. Vysoké gotické cihly, tzv. buchty, které byly v souboru z jižního křídla také hojně zastoupeny, se začínají 
na území Brna objevovat už od druhé poloviny 13. století, spíše však až od jeho konce do století patnáctého (Holub-Kolařík-Merta-Peška 2010, 153-154). Exempláře z výzkumu mají rozměry 27-28 × 13-13,5 ×8,5-9 cm. Ve stojících konstrukcích je tento typ cihel užit jako samostatný materiál pro valenou lehce lomenou klenbu sklepa a interiérové příčky, dále ve smíšeném zdivu přestaveb a později jako druhotně použitý stavební materiál. Jediná nalezená cihla netypického formátu měla rozměr $19 \times 16 \times 6,3 \mathrm{~cm}$. Na cihlách bylo možné pozorovat standardní stopy po výrobním procesu (podsypání formy, prstování povrchu), stejně jako stopy po jejich užití v konstrukci. Na cihlách se velmi často objevovaly otisky prstů a zvířecích tlapek. Ve stávajícím zdivu je možné dokumentovat také raně novověké cihly o rozměrech $28-29 \times 14,5-15 \times 7-7,5 \mathrm{~cm}$, jejichž užití je možné díky historickým pramenům datovat $s$ největší pravděpodobností do 16. století. Masově jsou zastoupeny cihly formátu $29,5-31 \times 15-15,5 \times 6-7 \mathrm{~cm}$ pocházející z přestaveb závěru 17.-19. století.

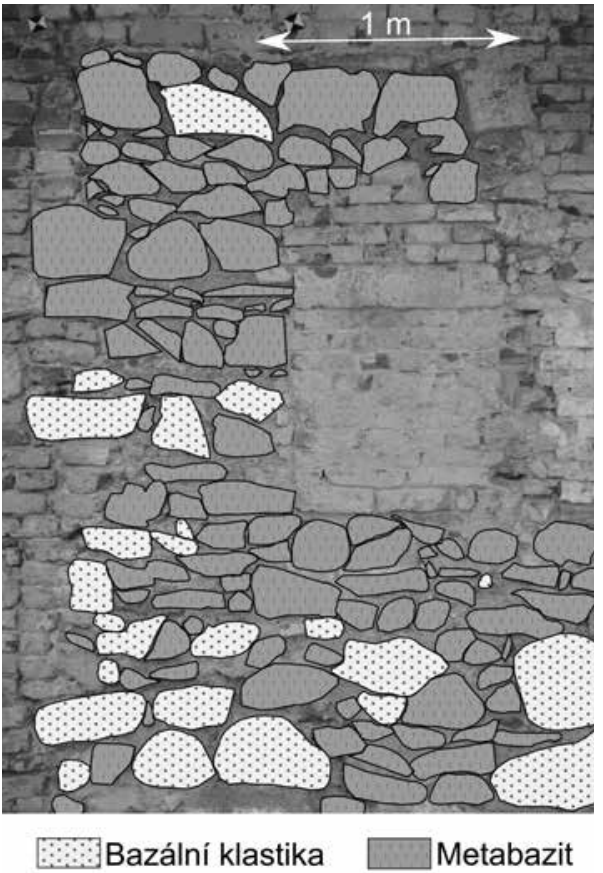

Obr. 2. Metoda měření procentuálního zastoupení jednotlivých druhủ hornin. Vzorek JK.

Abb. 2. Messmethode, wie die einzelnen Gesteinsarten prozentual vertreten sind. Probe des Südflügels.
Keramických dlaždic, na kterých bylo možné změřit alespoň dva rozměry, bylo vyzvednuto celkem 104 kusů, z čehož bylo 22 kusů glazovaných. Všechny patřily k dlaždicím čtvercového formátu $\mathrm{s}$ rozměry $17,5 \times$ $17,5 \times 3-3,5 \mathrm{~cm}$. Použitá glazura byla ve dvaceti př́ípadech zelená a ve dvou př́ípadech hnědá. Stejná úprava se vyskytuje na dlaždicích pocházejících ze starších výzkumů v jiných částech hradu (severní křídlo, východní křídlo, prostor před pětibokou věžicí). Datování dlaždic je obecně problematické, v případě glazovaných exemplářu je možné počítat s jejich výskytem od poloviny 13. století (Holub 2011, 115). Dlaždice byly původně součástí interiéru hradu a později byly $\mathrm{v}$ rámci některé $\mathrm{z}$ přestaveb strženy a použity do podlahových vyrovnávek. Jediný útržek keramické dlažby dochovaný in situ byl na Špilberku odhalen př̀ výzkumu zaniklého severního křídla hradu na velkém nádvoří v roce 1988 . V tomto případě však šlo o podlahu barokní př́istavby.

Během výzkumu v jižním křídle bylo vyzvednuto také 132 zlomků obloukové keramické krytiny. Stejně jako dlaždice nemá krytina ze sutových zásypů větší chronologický význam.

\section{Př́rodní stavební materiál z dochovaných částí hradu}

V návaznosti na zhodnocení stavební keramiky bylo provedeno určení přírodního stavebního materiálu hradu ve snaze revidovat dřívějši stanoviska. Z nich plynulo, že západní okrouhlá věž je nejstarší částí hradu nejen pro své tvarosloví, ale také kvůli užitému stavebnímu materiálu, který je rozdílný od zbytku hradu (Dvořák 1997, 170; Kolařík 2007, 38). Tyto závěry souvisely s otázkou týkající se založení hradu a započetí jeho výstavby (Cejnková-Loskotová-Plaček 1995, 156).

Z geologického hlediska se hrad Špilberk nachází na elevaci náležící metabazitové subzóně brněnského batolitu (Müller-Novák et al. 2000). Terénní úpravy - především hloubení př́ikopů a celkové úpravy temena kopce - jistě znamenaly, že metabazit byl nejsnáze dostupnou kamennou surovinou na lokalitě. Nicméně z pozorování J. Dvořáka vyplývá, že hlavním stavebním 
materiálem západní věže byl zelenavý granodiorit a slepenec typu „old red“" $\mathrm{z}$ asi $1,3-4 \mathrm{~km}$ vzdálených lomů.

Pro revizní identifikaci hornin byly vybrány čtyři odkryvy původního zdiva $\mathrm{v}$ různých částech hradu. Konkrétně se nacházely v prostoru jižního křídla (JK), západního křídla $(\mathrm{ZK})$, okrouhlé věže v západní části (ZV) a průjezdu ve východním křídle (VK). Na polygonech o rozměrech ca 1-2 $\mathrm{m}^{2}$ byly identifikovány všechny horniny, jejichž plocha byla kvantifikována pomocí nástrojů GIS (obr. 2). Horniny byly identifikovány kombinací makroskopického pozorování a měření magnetické susceptibility př́ručním kappametrem. Přítomnost karbonátů byla ověřena $20 \%$ roztokem $\mathrm{HCl}$.

Průzkumem byl v největší míře identifikován metabazit spolu s bazálními klastiky. V západním kř́idle a průjezdu se vyskytovaly také nafialovělé arkózové pískovce a pouze v průjezdu byly v menším množství zastoupeny také žlutošedé pískovce (odpovídající pískovcům karpatské předhlubně) a granodiorit. V souladu se starším tvrzením je granodiorit v západní věži zastoupen významnou mírou (obr. 3).

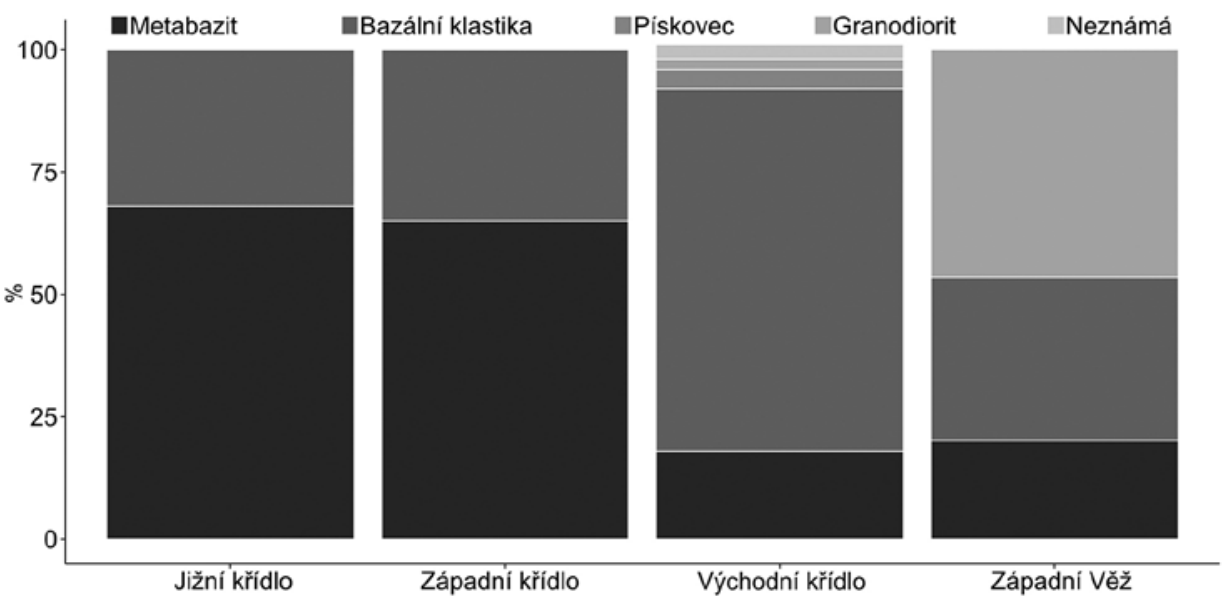

Obr. 3. Graf procentuálního zastoupení hornin v jednotlivých místech odběru vzorků.

Abb. 3. Diagramm mit prozentualem Vorkommen der Gesteine an den einzelnen Probeentnahmestellen.

Ze zkoumaných úseků zdiva vyplývá, že poměr a druh zastoupených hornin (metabazit/bazální klastika) v jižním a západním kř́ídle jsou téměř identické. Jediným rozdílem je skutečnost, že v západním kř́ídle se vyskytuje vedle slepenců také arkózový pískovec bazálních klastik. V prostoru okrouhlé věže byl zachycen nazelenalý granodiorit (pravděpodobně typ Blansko) uváděný v literatuře (Dvořák 1997). Vedle něj se však také vyskytoval významný podíl bazálních klastik tvořících podobně velké bloky, přičemž zaujímají přibližně stejně velkou plochu jako místní metabazity zastoupené především ve formě menších nepravidelných úlomků. Pro stavbu věže byly tedy z logistických nebo funkčních důvodů použity také granodiority, jež nebyly zjištěny v jižním křridle, ani v přístupné části západního křídla hradu.

Výrazně rozdílné složení bylo zachyceno v průjezdu, kde převládají slepence bazálních klastik nad metabazitem. Významně je zastoupen také terciérní pískovec. V blízkosti byly identifikovány jurské krinoidové vápence ze Stránské skály, které však byly mimo dokumentovaný polygon.

1 Pro tento druh horniny dále používáme obecnější termín „bazální klastika“, nebot’ zahrnuje všechny varianty zrnitosti a je aktuálně upřednostňován v geologické literatuře. 


\section{Analýza užitých malt}

Tři vzorky malt byly podrobeny mineralogicko-petrografické analýze pomocí optické mikroskopie a rtg-difraktometrie. ${ }^{2}$ Šlo o vzorky z jižního křídla (JK), západního křídla (ZK) a západní věže $(Z V)$. Původním cílem bylo pokusit se prokázat větší stáŕí malty ze západní věže než z ostatních míst odběru. Indicie dokládající rozdílný technologický postup výroby z jednotlivých vzorků malt, na jejichž základě bychom mohli předpokládat rozdílné období jejich vzniku, se touto metodou bohužel objevit nepodařilo. Stejně tak se nepodařilo prokázat hydraulicitu použitého vápna. Přesto však došlo - z hlediska středověké technologie vápenictví a stavitelství k mimořádně zajímavému objevu: ve vzorku z jižního křídla byla prokázána prrítomnost sklářské strusky (obr. 4). Podle rtg-difraktometrie je hlavní krystalickou fází strusky cristobalit (vysokoteplotní modifikace $\mathrm{SiO}_{2}$ ), který je zde prŕítomen v množství ca $10 \%$. Protože je tato struska převážně sklovitá, je její obsah v maltě dostatečný na to, aby svými pucolánovými vlastnostmi ovlivnila vlastnosti pojiva. Naskýtá se tedy otázka, zda je struska v maltě př́itomna náhodou, nedopatřením, nebo zda byl středověký stavitel obeznámen s antickými poznatky o př́iznivém působení vulkanického skla na pevnost a trvanlivost vápenné malty (Vitruvius 1979). Je třeba si uvědomit, že tato malta pochází z historického období, kdy převládalo přesvědčení, že čím je čistější vápno, tím lepší jsou vlastnosti malty. Použivání pucolánů bylo po antickém období zapomenuto a znovu objeveno až v 17. století (Hewlett 2004).

Ve vápenném nedopalu vzorku ze západní věže byly nalezeny zbytky fosilních lilijic, podle nichž lze jednoznačně určit, že vápno bylo páleno z vápence ze Stránské skály (obr. 5).

Kamenivo (písek) ve všech analyzovaných vzorcích malt pochází z místních bazálních klastik (,old red“) nebo z náplavů řeky Svratky.

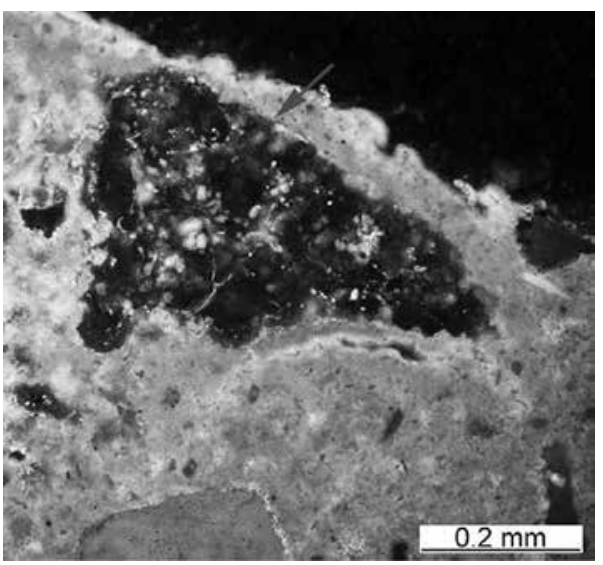

Obr. 4. Fragmenty sklářské strusky na výbrusu vzorku JK. Foto D. Všianský.

Abb. 4. Glasschlackenfragmente in einer Dünnschliffprobe des Südflügels. Foto D. Všianský.

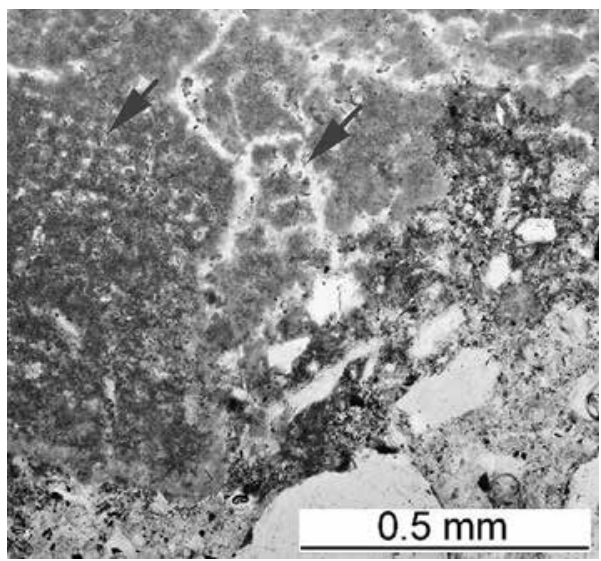

Obr. 5. Fosilní lilijice ve vápenném nedopalu na výbrusu vzorku ZV. Foto D. Všianský.

Abb. 5. Fossile Crinoiden in unvollständig gebranntem Kalk in einer Dünnschliffprobe des Westturms. Foto D. Všianský.

\section{Interpretace}

Vzorkování prŕírodního stavebního materiálu a možnost rámcové datace použitého formátu cihel nám spolu s ostatními poznatky archeologického a stavebně historického výzkumu v kombinaci s historickými prameny umožní vytvořit alespoň hrubou hypotézu o možných vývojových proměnách hradu od rané gotiky až do rozsáhlé barokní přestavby. Kromě materiálu získaného ze sond jsou pro časovou identifikaci klíčové odhalené stavební konstrukce. Ilustrativně

2 Za umožnění provedení rtg-difrakčních měření náleží poděkování projektu CEITEC - open access project, ID number LM2011020. 
můžeme charakter vývoje sledovat na struktuře vnitřní strany obvodové zdi gotického hradu v místnosti Jižní křídlo 110 (obr. 6), kde je možné na základě užitého stavebního materiálu a převrstvování konstrukcí rozeznat čtyřri stavební fáze. ${ }^{3}$ Pozorovaná zjištění korespondují s poznatky ze starších archeologických výzkumů i v jiných částech hradu.

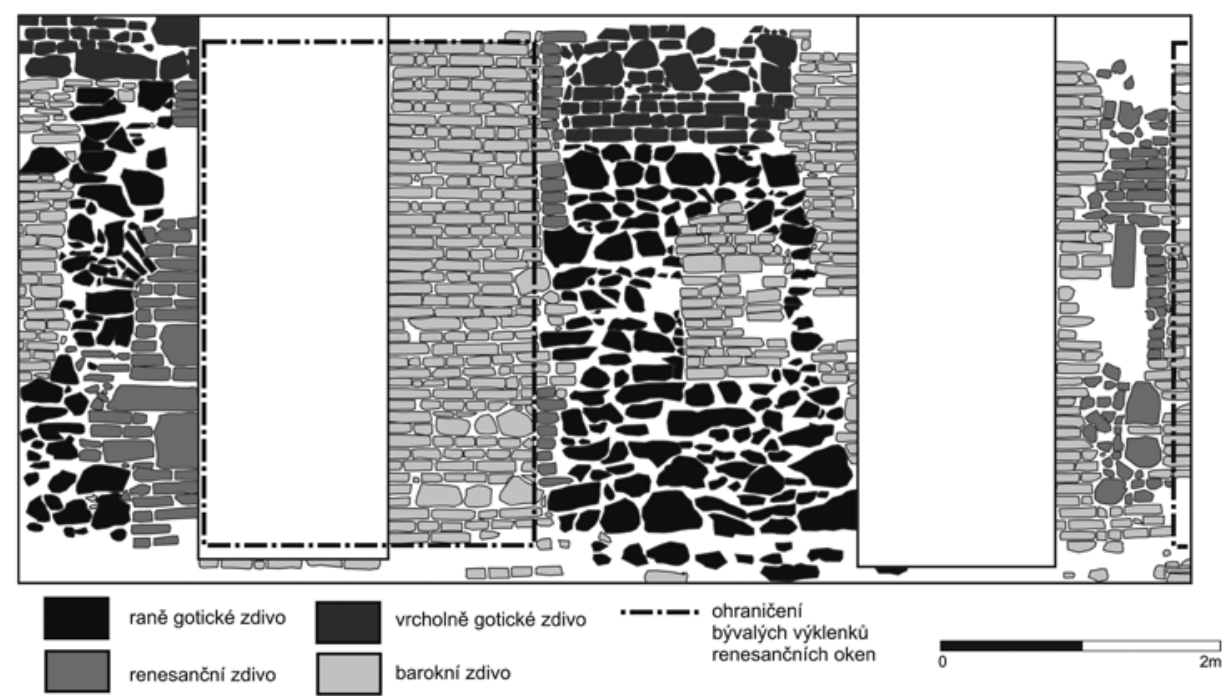

Obr. 6. Interpretační kresba situace na vnitřní stěně obvodové zdi hradu v místnosti Jižní křídlo 110. Kresba A. Navrátil. Abb. 6. Interpretationszeichnung der Situation an der Innenwand der Wehrmauer in Raum 110 des Südflügels. Zeichnung A. Navrátil.

\section{Raně gotická fáze}

Nejstarší stavební fáze je logicky spojována s výstavbou hradu. Charakteristickým a nejvíce zastoupeným materiálem této fáze je lomový metabazit (získávaný při terénní úpravě temena špilberského kopce a hloubení západního a východního příkopu), bazální klastika - konkrétně devonská bazální klastika typu „old red“ - a cihly malého formátu. Vše bylo pojeno charakteristickou oranžově zbarvenou hrubozrnnou maltou. Cihly byly používány nejčastěji do výplní žebrových kleneb a zaklenutí výklenků, jak je patrno např. na rubu klenby gotického sálu ve východním křídle (obr. 7), nebo v dochovaném prevetu v severním křídle. I v rámci této nejstarší fáze můžeme sledovat jistou časovou posloupnost.

Jak již bylo zmíněno, z hlediska skladby stavebního materiálu výrazně vyčnívá západní okrouhlá věž, kde je téměř z $50 \%$ zastoupen granodiorit, který se s výjimkou nepatrného výskytu ve východním průjezdu v jiných sondách nevyskytuje. V souladu se staršími hypotézami vyslovenými nejprve na základě morfologie věže a následně i skladby stavebního materiálu se zdá, že stavba věže skutečně předcházela výstavbě zbytku hradu (Cejnková-Loskotová-Plaček 1995, 156; Dvořák 1997, 170). Jako př́íspěvek k této otázce můžeme přiložit stratigrafické pozorování učiněné v místě, kde se relikt budovy západního křídla připojuje k věži (obr. 8). Z profilu je zřejmé, že základ věže (1) byl zahlouben do metabazitového podloží a následně překryt vrstvou metabazitového štěrku (B) a vrstvou jílu (A). Konstrukce základu budovy západního křídla (2) nejenže má rozdílnou stavební skladbu (prakticky identickou se skladbou v jižním křídle), ale je také až dodatečně zahloubena do vrstvy $\mathrm{B}$, nasedá na metabazitové podloží a $\mathrm{k}$ věži přisedá spárou. Je tedy mladší. Bohužel v současné době není možné pozorovat napojení hlavní obvodové zdi hradu na věž, které by pomohlo odhalit vzájemný vztah, nebot' vzorkem ZK dokumen-

3 Za cenné prŕspěvky z hlediska stavebně historického průzkumu děkujeme $Z$. Chudárkovi. 
tované zdivo budovy západního křídla může být až dodatečnou př́ístavbou k západní obvodové zdi. ${ }^{4}$ Pokud vezmeme v úvahu poměrově nižší zastoupení metabazitu vzhledem ke zbytku hradu dostává teorie o prioritní výstavbě věže další argument. Mohlo k ní dojít ještě před započetím hloubení hradních př́íkopů. Kámen byl proto z valné většiny dovážen z lomů na Červeném kopci a z údolí Svratky.

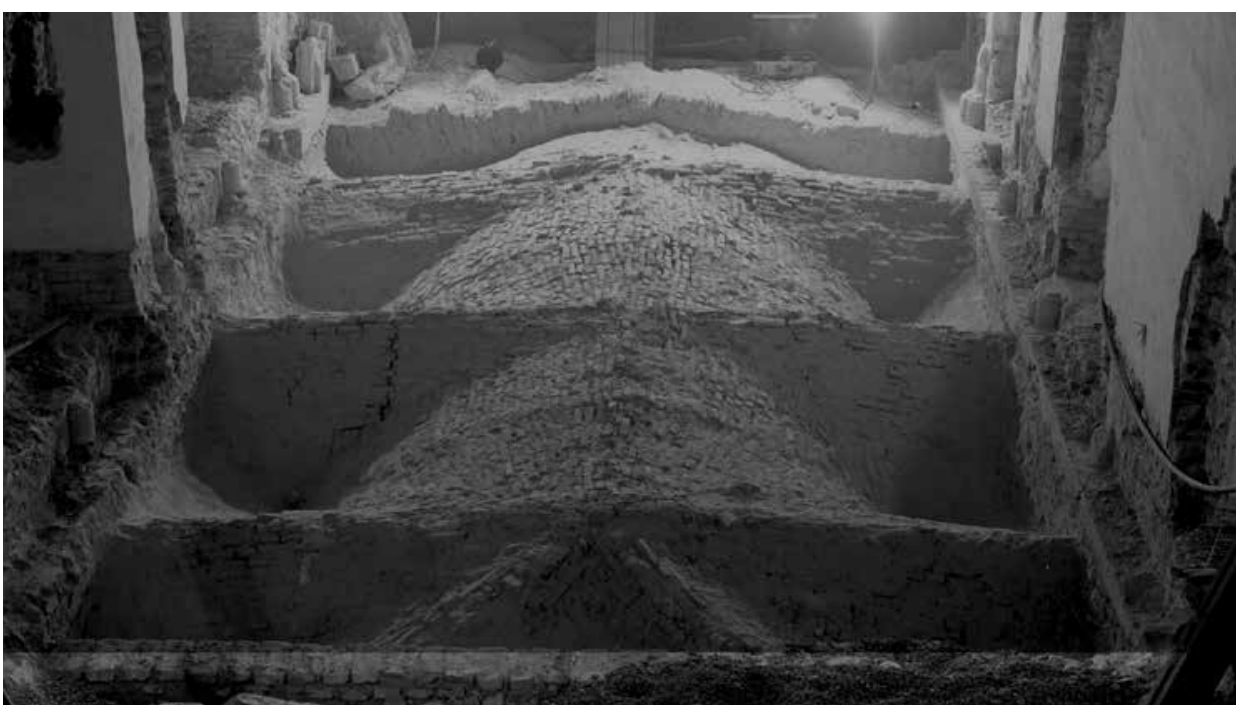

Obr. 7. Hrad Špilberk. Rub žebrové klenby přízemního gotického sálu ve východním křídle. Foto K. Šabata.

Abb. 7. Burg Spielberg. Oberseite des Kreuzrippengewölbes des gotischen Saales im Ostflügel. Foto K. Šabata.

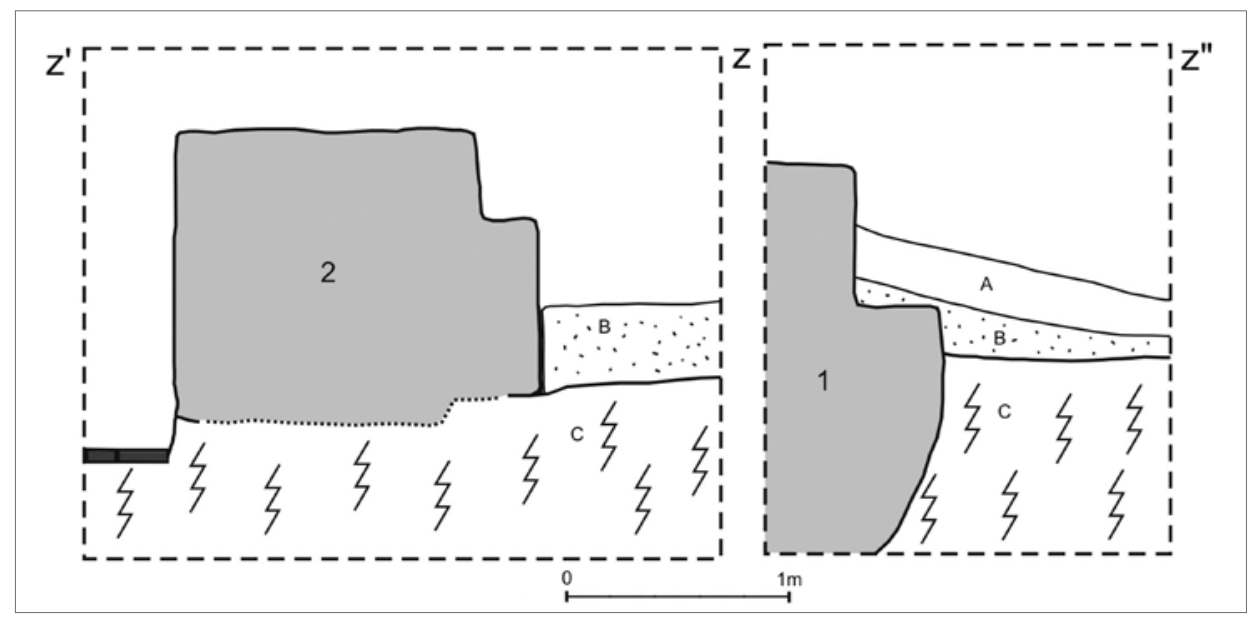

Obr. 8. Hrad Špilberk. Stratigrafická situace v místě napojení zdiva západního křídla na okrouhlou věž. Abb. 8. Burg Spielberg. Stratigraphische Situation an der Anschlussstelle von Westflügel und Rundturm.

\footnotetext{
4 Podle autorů D. Cejnkové, I. Loskotové a M. Plačka může i západní část obvodové zdi hradu souviset s nejstarší fází výstavby (v užším slova smyslu), nebot' zde byly pozorovány „velké kamenné kvádry kladené do řad a vrstev, tedy románskou technikou“ (Cejnková-Loskotová-Plaček 1995, 156). Fotodokumentace vnější strany zdi západního křídla v místě napojení na kruhovou věž po otlučení omítek sice ukazuje absenci spáry, nicméně výše uvedené tvrzení o využití kvádrů v tělese zdi nijak nepotvrzuje. ,Mohutné tesané kvádry“ zmiňované M. Plačkem (2013, 623), které jsou dnes díky památkové prezentaci přistupné, se nacházejí v jihozápadním nároži hradu a ve stěnách původního západního průjezdu do hradu (obr. 1). Pravděpodobně tedy jde spíše o provedení armatury nároži a průjezdu než o použití jako hlavního stavebního materiálu.
} 
Jako druhou raně gotickou subfázi je možné na základě dokumentovaných vzorků označit obvodové zdivo hradu v jižním křídle a již zmiňovanou vnitřní zástavbu západního křídla. Zastoupení hornin - metabazitu a slepence - je zde prakticky identické. Makroskopickým pozorováním stavebního materiálu lze k této subfázi řadit vznik valné většiny gotického hradu. Různorodost materiálu ve východním průjezdu je možné vysvětlit moderními rekonstrukcemi, které proběhly ve 40. a 80.-90. letech 20 . století.

Jako třetí subfáze mohou být označeny změny či dostavby interiéru a výstavba parkánové hradby. K jejímu vyčlenění došlo makroskopickým pozorováním stavebního materiálu v průběhu záchranného výzkumu v jižním křídle. Z něj vyplývá, že parkánová hradba dokumentovaná v sondách JK007, JK008 a JK0010 byla vystavěna pouze z metabazitu. Stejnou jednolitou skladbu má vnitřní prríčka jižního křídla v sondě JK012, která navíc nasedá k obvodové zdi hradu spárou. Bohužel v době geologického vzorkování byly tyto konstrukce již nepřístupné, nejsou proto součástí výše prezentované analýzy. Vyčlenění této subfáze odpovídá obecné teorii o dodatečné dostavbě parkánu (Navrátil 2013).

Nechceme se na tomto místě pouštět do úvah o dataci založení hradu, které se vzhledem k nedostatku pramenů mohou pohybovat pouze v rovině hypotéz. Rádi bychom však upozornili, že tři výše naznačené subfáze raně gotické éry hradu nemusí nutně znamenat tři časově oddělené fáze stavby, ale mohou být odrazem relativně kontinuálních stavebních etap v průběhu mnoho let trvající výstavby. Různorodost stavebního materiálu jednotlivých subfází může reflektovat strategii využívání stavebního materiálu na základě jeho dostupnosti, která se mohla v průběhu výstavby měnit - napřr. při hloubení příkopů je logické předpokládat, že nejvyužívanější byl metabazit, zatímco při prvotních terénních úpravách temena kopce bylo třeba místní kámen významně doplňovat odjinud. Pro celou raně gotickou fázi je totiž charakteristický stejný typ užité oranžové malty, kterou známe z brněnské měšt’anské kamenné architektury. Její užívání je v této souvislosti datováno do poslední třetiny 13. století a prvních desetiletí století čtrnáctého (Merta 2001, 57).

\section{Vrcholně gotická fáze}

Další stavební fáze rozpoznatelná stavebně historickou metodou je reprezentována konstrukcemi z velkoformátových cihel, tzv. buchet, zděnými na bílou vápennou maltu. Jejich zástupcem je zejména zcela dochovaná lehce lomená valená klenba sklepa v suterénu jižního křídla (konstrukce 906) a na ni nasedající relikt interiérové příčky odhalené v sondě JK003 (konstrukce 904). Drobný, ale výmluvný útržek zdiva s výrazným využitím velkoformátových cihel se dochoval také v místnosti 110 jako úprava vnitřní strany obvodové zdi hradu ve výšce zhruba 3 metrů nad současnou podlahou (obr. 6). Tyto konstrukce zjevně reagují na již stojící zdivo předchozí stavební fáze a v př́ípadě obvodové zdi ji od výšky prvního patra upravují. Stavební materiál předchozích fází, tedy cihly malého formátu, lomový metabazit a bazální klastika, jsou v konstrukci obsaženy také.

Při pohledu do historie hradu ohraničené výskytem velkoformátových cihel (14.-15. století) je nasnadě, že tak rozsáhlé přestavby zahrnující vestavění sklepa, změnu rozvržení interiéru a zásahy do obvodového zdiva se mohly udát s největší pravděpodobností v době, kdy byl Špilberk sídlem moravských markrabat Jana Jindřicha a Jošta, tedy mezi lety 1349 a 1411 (Plaček 2013, 616). V následných dobách epizodického stř́idání správců na pozadí dramatických událostí 15. století jsou přestavby tohoto rozsahu jen těžko představitelné.

\section{Renesanční fáze}

Třetí stavební fází je možné souhrnně označit stavební zásahy provedené v průběhu 16. století. O jejich existenci svědčí jak stavební materiál, tak historické a ikonografické prameny. V místnosti 110 se třetí fáze projevuje stopami po proražení dvou pravoúhlých oken. Z nich se ve zdivu dochovala část ostění a armatury dvou okenních výklenků. Jako hlavní stavební 
materiál byly použity cihly již novověkého formátu, doplňované v malé míře cihlami vysokého formátu získanými ze snesených konstrukcí předchozí stavební fáze. Další zcela zachované renesanční okno bylo restaurováno ve východní fasádě východního křídla a ostění dalšího je památkově prezentováno ve vnějším líci severní obvodové zdi. Hrad v této fázi je i s pravoúhlými okny velice popisně zachycen na slavné vedutě Obleženi Brna Švédy z roku 1646 (obr. 9). Mezi další projevy renesanční fáze můžeme s největší pravděpodobností řadit archeologickými výzkumy zachycené sut’ové vyrovnávky obsahující stavební materiál charakteristický pro fáze předchozí - tedy raně gotické cihly malého formátu a vysokoformátové „buchty“.

$Z$ historických pramenů víme, že v roce 1543 projevili moravští stavové na zemském sněmu již několikrát opakované znepokojení nad žalostným stavem hradu, který měl být strategickým bodem v př́ípadě vojenského ohrožení, jež hrozilo ze strany Osmanské říše. Situace vyústila $\mathrm{v}$ odebrání hradu zástavním držitelům a jeho předáním do přímé správy. $Z$ tohoto období, konkrétně z roku 1552, se dochoval Inventár̆ panství Špilberského 1552, který dokládá provedené stavební zásahy. Konkrétně jsou mimo jiné zmiňovány nové pokoje a nová okna. Nakolik byly tyto stavební zásahy rozsáhlé a zda můžeme zmiňovaná okna ztotožňovat s dochovanými relikty, není jasné. Již v roce 1553 totiž prosil nový správce hradu císaře o prostředky na stavební materiál (Vaněk 2014).

Další rozsáhlé stavební aktivity je možné předpokládat v roce 1593 v souvislosti s výstavbou renesančního fortifikačního prstence (Navrátil 2013). Zda tyto přestavby zahrnovaly také areál gotického hradu a jeho interiér, není možné zjistit. Nicméně z hlediska jistě mimořádné nákladnosti výstavby renesančního opevnění z městských prostředků se jeví tato možnost velmi nepravděpodobnou.

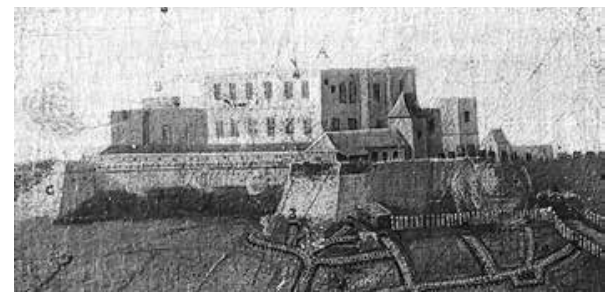

Obr. 9. Výřez z veduty Obležení Brna Švédy z roku 1646. Bayer, Zeiser, Muzeum města Brna, inv. č. 2285.

Abb. 9. Ausschnitt aus der Stadtansicht Belagerung Brünns durch die Schweden aus dem Jahr 1646. Bayer, Zeiser, Museum der Stadt Brno, Inv.-Nr. 2285.

\section{Barokní a následující fáze}

Čtvrtou fází rozpoznatelnou na vnitřní stěně obvodové zdi v místnosti 110 je přestavba hradu na barokní citadelu. Ta byla započata v 70. letech 17. století a v různých vývojových etapách pokračovala až do druhé poloviny století osmnáctého. Následovalo mnoho dalších významných přestaveb jako např. v 19. století v souvislosti s vězeňskou funkcí hradu, dále pak ve 20. století za nacistické okupace. Vynechat nelze ani historizující rekonstrukce provedené na konci 90 . let 20. století a po roce 2000. Těmto přestavbám však již byly věnovány jiné statě (např. Vaněk 2008; Kroupa 1990; Chudárek 2000).

\section{Závěr}

Díky analýze keramického a prŕrodního stavebního materiálu pocházejícího převážně z výzkumu v jižním křídle z let 2011-2012 jsme získali možnost revidovaného pohledu na stavebně historický vývoj hradu Špilberk od jeho vzniku. Dokumentovaný materiál pocházel jak z archeologických sond, tak ze stavebně historického pozorování. Zatímco stavebně technická keramika nám umožnila rámcově určit hlavní vývojové fáze hradu, přírodní materiál poukázal na dílčí vývojové změny v průběhu té nejstarší z nich. Důležité poznatky o technologii výroby užitého stavebního pojiva přinesla mikroskopická analýza vzorků malt.

Na základě výše popsaného pozorování jsme schopni určit čtyři základní vývojové fáze hradu počínající jeho vznikem a uzavřené přestavbou na barokní citadelu. První, raně gotická fáze je charakterizována stavebním materiálem, kterým byl lomový kámen a v menší míře cihly malého formátu. Vše bylo pojeno oranžovou hrubozrnnou maltou. V rámci této fáze je díky analýze zastoupení užitého kamene možno rozpoznat tři subfáze. Tu nejstarší představuje 
západní okrouhlá věž s téměř padesátiprocentním zastoupením granodioritu vedle velkých bloků devonských bazálních klastik typu „old red“ a menších zlomků metabazitu. Mladší subfázi představuje valná většina zejména vnějšího zdiva hradu, které se vyznačuje podobným zastoupením metabazitu a bazálních klastik v poměru ca 3:2. Nejmladší subfázi představuje parkánová zed' a některé vnitřní příčky hradu, které jsou budovány téměř výhradně z metabazitu. Druhá stavební fáze hradu se vyznačuje užitím cihel velkého formátu, tzv. buchet, pojených vápennou maltou. Poměrně rozsáhlé přestavby je možné spojovat s rezidenční funkcí hradu v době působení moravských lucemburských markrabat v druhé polovině 14. století. Jako třetí fázi můžeme označit renesanční, zejména interiérové úpravy hradu v průběhu 16. století, které vyvrcholily výstavbou renesančního bastionového opevnění v roce 1593. Jako čtvrtou fázi označujeme řetězec přestaveb zahájený v 70. letech 17 . století a trvající až do závěru století osmnáctého, kdy se hrad změnil v barokní citadelu coby součást brněnské bastionové pevnosti. Konec strategické vojenské funkce znamenala pro Špilberk demolice nejdůležitějších fortifikačních prvků francouzskou armádou v roce 1809. Následné klasicistní a historizující přestavby pro vězeňské, kasárenské a muzejnické účely již nejsou předmětem této statě.

\section{Literatura}

CEJNKOVÁ, D.-LOSKOTOVÁ, I.-PLAČEK, M., 1995: Předběžné výsledky archeologického výzkumu Špilberku, BMD 13, 150-163.

DVOŘÁK, J., 1997: Stavební kámen starší středověké architektury v Brně. In: Z pravěku do středověku. Sborník k 70. narozeninám Vladimíra Nekudy, 165-174. Brno.

FLODROVÁ, M., 1988: Nejstarší dějiny Špilberku ve světle písemných pramenů. In: Forum Brunense 1988, 9-14. Brno: Muzeum města Brna.

HEWLETT, P., 2004: Lea's Chemistry of Cement and Concrete, 4th ed. London: Butterworth Heinmann.

HOLUB, P., 2011: K výrobě a variabilitě stavební keramiky ve středověkém a novověkém Brně - Die Produktion und Variabilität der Baukeramik im mittelalterlichen und euzeitlichen Brünn. In: Forum urbes medii aevi VI Surovinová základna a její využití ve středověkém městě, 98-121. Brno.

HOLUB, P.-KOLAŘÍK, V.-MERTA, D.-PEŠKA, M., 2010: Středověká brněnská architektura z cihel. In: Dějiny staveb. Sborník příspěvků z konference Dějiny staveb 2010, 139-159. Plzeň.

CHUDÁREK, Z., 2000: Př́íprava a metoda obnovy východního křídla hradu Špilberk v letech 1985-2000. In: Tocháček, P. a kol., Znovuzrození hradu. Prezentační publikace stavební společnosti Tocháček, s.r.o., Brno, vydaná u př́ležitosti dokončení stavební části východního křídla NKP Špilberk, 15-38. Brno.

KOLAŘÍK, V., 2007: Opevnění města Brna do konce třicetileté války na základě archeologických výzkumů, rkp. nepublikované diplomové práce, ulož. v ÚAM FF MU.

KROUPA, P., 1990: Špilberk - stavební úpravy za 2. světové války. In: Forum Brunense 1990, 95-106. Brno: Muzeum města Brna.

KUČA, K., 2000: Brno. Vývoj města, předměstí a připojených vesnic. Praha - Brno.

MERTA, D., 2001: Nejstarší měšt’anská kamenná architektura v Brně, PRP 8, č. 2, 41-60.

MÜLLER, P.-NOVÁK, Z. et al., 2000: Geologie Brna a okolí. Brno.

NAVRÁTIL, A., 2013: Vývoj vnějšího opevnění Špilberku - výsledky archeologických výzkumů 2010-2013, Svorník 11, 71-77.

PLAČEK, M., 2013: Brněnský hrad (Špilberk). In: Dějiny Brna 2 (Ján, L., ed.), 615-624. Brno.

VANĚK, J., 2008: Stavební proměny Špilberku v 1. polovině 18. století. In: Forum Brunense 2008, 525. Brno: Muzeum města Brna.

- 2014: Nejstarší špilberský inventář z roku 1552. In: Forum Brunense 2014, 7-18. Brno: Muzeum města Brna.

VITRUVIUS POLLIO, M., 1979. Deset knih o architektuře. Praha: Svoboda.

\section{Zusammenfassung}

\section{Der Baustoff der Burg Spielberg und seine Entwicklung}

Die in den Jahren 2011-2012 im Südflügel der Burg Spielberg durchgeführte archäologische Rettungsgrabung brachte über die Entwicklung der Burg eine Fülle von wichtigen Erkenntnissen. Unter anderem lieferte sie eine reiche Kollektion Baukeramik und ermöglichte 
zahlreiche bauhistorische Beobachtungen. Die Situation wurde auch für eine geologische makroskopische Beobachtung der natürlichen Baustoffe und für eine mikroskopische Analyse der benutzten Bindemittel genutzt.

Die aus den archäologischen Sondiergrabungen gewonnenen Baustoffe lassen sich in Ziegel, Dachbedeckungen und Fliesen untergliedern. An Ziegeln wurden 101 Stück entdeckt. Im 13. Jahrhundert waren flachformatige Ziegel im Stadtgebiet Brünn zahlreich vertreten. Ihre Verwendung endete an der Wende vom 13. zum 14. Jahrhundert.

Gotische Hochziegel, sog. Buchteln, die in der Kollektion des Südflügels ebenfalls zahlreich vertreten waren, beginnen im Brünner Stadtgebiet bereits ab der zweiten Hälfte des 13. Jahrhunderts, jedoch eher erst ab dessen Ende bis zum 15. Jahrhundert, aufzutauchen. An quadratischen Fliesen wurden 104 Stück entdeckt, von denen 22 grün glasiert waren. Die Datierung der Fliesen ist sehr problematisch, weswegen sie nur grob erfolgte und in den Zeitraum vom 13. bis zum 15. Jahrhundert gelegt wird.

Für die Revisionsidentifikation des natürlichen Bautoffs wurden vier in verschiedenen Teilen der Burg freigelegte Stellen des ursprünglichen Mauerwerks ausgewählt. Sie befanden sich im Bereich des Südflügels (JK), Westflügels (ZK), des Rundturms im Westteil (ZV) und der Durchfahrt im Ostflügel (VK). Aus den untersuchten Mauerwerksabschnitten geht hervor, dass Verhältnis und Art der darin vertretenen Gesteine (Metabasit/basale Klasten) im Süd- und Westflügel fast identisch sind. Freilich mit dem Unterschied, dass im Westflügel neben Brekzien auch Feldspatsandstein basaler Klasten vorkommt. Im Bereich des Rundturms wurde auch grünlicher Granodiorit entdeckt.

Ursprünglich bestand das Ziel der mineralogisch-petrographischen Analyse des Bindemittels in dem Versuch nachzuweisen, dass die Mörtel aus dem Westturm ein größeres Alter als an den übrigen Entnahmeorten haben. Das wurde jedoch nicht bestätigt. Eine interessante Erkenntnis ist die Feststellung einer Beimischung von Glasschlacke, was ein Beleg dafür sein kann, dass die Qualitätseigenschaften des Bindemittels gezielt verbessert wurden.

Die Ergebnisse der Grabung und die oben aufgeführten Daten erlauben es, eine grobe Hypothese darüber aufzustellen, welche möglichen Entwicklungswandlungen die Burg von der Frühgotik bis zu ihrem barocken Umbau durchgemacht hat. Es lassen sich 4 Bauphasen unterscheiden. 1. Die frühgotische Phase ist durch die Verwendung von Bruchmaterial und gotischen Flachziegeln charakteristisch. Ihr Anfang wird in das zweite Drittel des 13. Jahrhunderts gelegt. Der Verwendung von Granodiorit nach scheint es, dass der runde Westturm errichtet wurde, bevor der Rest der Burg gebaut wurde. Die 2. Phase zeichnet sich durch die Verwendung von Hochziegeln aus und kann mit dem Wirken der mährischen Markgrafen aus der Dynastie der Luxemburger in Verbindung gebracht werden. Die 3. Phase fällt in die Renaissancezeit, als es im Interieur zu Umbauten kam und der Bastionsring gebaut wurde. Als 4. Phase bezeichnen wir den in den siebziger Jahren des 17. Jahrhunderts begonnenen Umbau zu einer Barockzitadelle.

Mgr. Aleš Navrátil, Muzeum města Brna, Špilberk 1, 66223 Brno, navratil@spilberk.cz

Mgr. Monika Martinisková, Ústav archeologie a muzeologie Filozofické fakulty Masarykovy univerzity, Arna Nováka 1, 60200 Brno, martiniskova@yahoo.com

Mgr. Jan Petřík, Ústav geologických věd Př́rodovědecké fakulty Masarykovy univerzity, Kotlářská 2, 61137 Brno,jpazourek@email.cz

Mgr. Dalibor Všianský, Ph.D., Ústav geologických věd Př́rodovědecké fakulty Masarykovy univerzity, Kotlářská2,61137Brno, dalibor@sci.muni.cz 
